\title{
CRIME SEVERITY AND CONSTITUTIONAL LINE-DRAWING
}

\author{
Eugene Volokh*
}

\section{INTRODUCTION}

Some speech risks inciting or aiding serious crimes. Other speech risks causing only minor crimes. Some searches and seizures are aimed at catching kidnappers, others at catching bookies.

Should constitutional doctrine draw lines that turn on crime severity? And if it should, how should these lines be drawn? Commentators and judges have often urged that the first question be answered "yes." After all, if courts are to balance

* Professor, UCLA Law School (volokh@law.ucla.edu). Thanks to Steve Bibas, Orin Kerr, David Lundeen, and David Sklansky for their help.

${ }^{1}$ See, e.g., Atwater v. City of Lago Vista, 532 U.S. 318, 365 (2001) (O'Connor, J., dissenting) (as to warrantless arrests); United States v. Sharpe, 470 U.S. 675, 689 n.1 (1985) (Marshall, J., concurring in the judgment) (as to Terry v. Ohio stops); New Jersey v. T.L.O., 469 U.S. 325, 379-81 (1985) (Stevens, J., dissenting) (as to searches of public school students); Gustafson v. Florida, 414 U.S. 260, 266-67 (1973) (Stewart, J., concurring) (as to warrantless arrests); Dennis v. United States, 341 U.S. 494, 510 (1951) (plurality) (as to speech aimed at producing criminal conduct); Brinegar v. United States, 338 U.S. 160, 183 (1948) (Jackson, J., dissenting) (as to the Fourth Amendment generally); McDonald v. United States, 335 U.S. 451, 459 (1948) (Jackson, J., concurring) (as to the Fourth Amendment generally); Whitney v. California, 274 U.S. 357, 378 (1927) (Brandeis, J., concurring in the judgment) (as to speech aimed at producing criminal conduct); Llaguno v. Mingey, 763 F.2d 1560, 1566-67 (7th Cir. 1985) (as to probable cause needed to search); United States v. Soyka, 394 F.2d 443, 452 (2d Cir. 1968) (Friendly, J., dissenting) (as to exclusionary rule); United States v. Queen, 26 M.J. 136, $140 \&$ n.1 (Ct. Mil. App. 1988) (as to probable cause needed for a search authorization); Park v. Forest Service, 69 F. Supp. 2d 1165, 1175-76 (W.D. Mo. 1999) (as to propriety of police checkpoint); State v. Bolt, 689 P.2d 519, 530 (Ariz. 1984) (Cameron, J., specially concurring) (as to exclusionary rule); People v. Sirhan, 497 P.2d 1121 (Cal. 1972) (as to exigent circumstances and probable cause); People v. Schader, 401 P.2d 665, 669 (Cal. 1965) (as to probable cause), overruled on other grounds by People v. Cahill, 853 P.2d 1037 (Cal. 1993); Akhil Reed Amar, Fourth Amendment First Principles, 107 HARV. L. REV. 757, 801-02 (1994) (as to Fourth Amendment generally); Craig M. Bradley, Two Models of the Fourth Amendment, 83 MicH. L. Rev. 1468, 1491, 1500 (1985); James Duke Cameron \& Richard Lustiger, The Exclusionary Rule: A CostBenefit Analysis, 101 F.R.D. 109, 145 (1984) (as to exclusionary rule); Sherry F. Colb, The Qualitative Dimension of Fourth Amendment "Reasonableness," 98 CoLUM. L. REV. 1642, 1645 (1998) (as to searches generally); M.K.B. Darmer, Beyond Bin Laden and Lindh: Confessions Law in an Age of Terrorism, 12 CORNELl J.L. \& PUB. POL'Y 319, 368-69 (2003) (as to "shock the conscience" test under the Due Process Clause); Interview with Alan M. Dershowitz, 60 Minutes, CBS News, Jan. 20, 2002 (as to prohibition of torture); John Kaplan, The Limits of the Exclusionary Rule, 26 StAN. L. REV. 1027, 1046-47 (1974) (as to exclusionary rule); Wayne R. LaFave, "Street Encounters" and the Constitution: Terry, Sibron, Peters and Beyond, 67 MicH. L. REV. 39, 57 (196869) (as to Terry v. Ohio stops); Craig S. Lerner, The Reasonableness of Probable Cause, 81 TeX. L. REv. 951, 970-71, 1016-17 (2003) (as to probable cause); Wayne A. Logan, Street Legal: The Court Affords Police Constitutional Carte Blanche, 77 IND. L.J. 419, 458 (2002) (as to warrantless arrests); Erik Luna, Drug Exceptionalism, 47 VILL. L. REV. 753, $781-87$ (2002) (summarizing but criticizing 
constitutional rights against government interests, and the government interest is in preventing crime, the weight of the government interest must turn on the seriousness of the crime the government is trying to avert. ${ }^{2}$ Constitutional law shouldn't be forced into unitary rules that underprotect rights when the government interest in preventing a crime is minor, or underprotect government power when the government interest is great.

And yet the trouble with a "yes" answer is that it requires courts to answer the second question-a question that is thorny indeed. People often bitterly disagree about how severe various crimes are. To some, many drug crimes are comparatively minor, ${ }^{3}$ or shouldn't be crimes at all. To others, they are next to murder. To some, white-collar crimes, as nonviolent offenses, are relatively minor. To others, they are the moral equivalent of armed robbery, different chiefly in the wealth and social standing of the criminals. ${ }^{4}$ Likewise, there are disagreements about the seriousness of copyright infringement, burglary, ${ }^{5}$ and other offenses.

Even the classic and oft-praised ${ }^{6}$ opinion that urges courts to draw severity distinctions, Justice Jackson's 1949 dissent in Brinegar v. United States, illustrates

some such arguments made as to searches); Richard A. Posner, Rethinking the Fourth Amendment, 1981 SuP. CT. REV. 49, 74-75 (as to searches generally); Martin Redish, Advocacy of Unlawful Conduct and the First Amendment: In Defense of Clear and Present Danger, 70 CAL. L. REV. 1159, 1179-80 (1982) (as to speech aimed at producing criminal conduct); William J. Stuntz, O.J. Simpson, Bill Clinton, and the Transsubstantive Fourth Amendment, 114 HARV. L. REV. 842, 852 (2001) (as to Fourth Amendment generally); Eugene Volokh, Crime-Facilitating Speech (circulated for publication) (as to speech communicating information that may help some recipients commit crimes).

${ }^{2}$ I say "avert" rather than "punish," but the two go hand in hand: Punishing past murders, for instance, is seen as particularly likely to avert future murders, or at least future serious violent crimes, because murderers tend to be more likely to commit other violent crimes (though of course that need not be so as to each individual murderer). See, e.g., U.S. DEP'T OF JUSTICE, BurEAU OF JUSTICE STATISTICS, FELONY DEFENDANTS IN LARGE URBAN COUNTIES, 1998, at 10-11 (reporting that 81\% of felony murder defendants in the nation's 75 largest urban counties had an arrest record, and $67 \%$ had a felony arrest record).

${ }^{3}$ Cf., e.g., Stuntz, supra note 1, at 852 (suggesting that under the Fourth Amendment probable cause and a warrant shouldn't be enough to justify searches of homes in cases of "less-than-serious drug cases - anything associated with marijuana would be a good example," though it should be enough to justify such searches where serious crimes, such as murder, are involved); cases cited infra note 39.

4 "Some will rob you with a six-gun, and some with a fountain pen." Woody Guthrie, Pretty Boy Floyd, on Folkways, the Original Vision (Smithsonian Folkways 1989, 1940); THE WoODY GUTHRIE SONGBOOK 187 (Harold Leventhal \& Marjorie Guthrie eds. 1976). The line may have referred to noncriminal use of fountain pens (for instance, in foreclosure and the like), but presumably it would a fortiori apply to white-collar crime.

5 Compare, e.g., Tennessee v. Garner, 471 U.S. 1, 21 (1985) (reasoning that burglary isn't a serious enough crime to justify use of deadly force to stop a fleeing burglary suspect) with id. at 23 (O'Connor, J., dissenting) (criticizing the majority for "disregarding the serious and dangerous nature of residential burglaries"); infra note 40.

${ }^{6}$ See, e.g., Amar, supra note 1, at 801-02; William J. Stuntz, Local Policing After the Terror, 111 YALE L.J. 2137, 2140 n.8 (2002); Darmer, supra note 1, at 368-69. 
this difficulty. Justice Jackson eloquently argued that the government should have less power to engage in searches and seizures when it's pursuing petty criminals, such as alcohol smugglers, ${ }^{7}$ than when it's pursuing serious criminals, such as kidnappers. But alcohol causes many deaths, many crimes, and much other harm. Today, for instance, alcohol use is implicated in 100,000 deaths each year, including likely about 10,000 deaths of innocent bystanders. ${ }^{8}$ Oklahoma-the state into which Brinegar was trying to smuggle alcohol-was a dry state from its admission into the union until 1959, and it never ratified the Twenty-First Amendment. ${ }^{9}$ The Oklahoma legislature may have viewed alcohol smuggling as far from a petty offense, ${ }^{10}$ and it's

${ }^{7}$ Brinegar v. United States, 338 U.S. 160, 182 (1948) (Jackson, J., dissenting):

[I]f we are to make judicial exceptions to the Fourth Amendment [because of the special nature of cars], it seems to me they should depend somewhat upon the gravity of the offense. If we assume, for example, that a child is kidnaped and the officers throw a roadblock about the neighborhood and search every outgoing car, . . . I should candidly strive hard to sustain such an action, executed fairly and in good faith, because it might be reasonable to subject travelers to that indignity if it was the only way to save a threatened life and detect a vicious crime. But I should not strain to sustain such a roadblock and universal search to salvage a few bottles of bourbon and catch a bootlegger.

See also McDonald v. United States, 335 U.S. 451, 459 (1948) (Jackson, J., concurring) (taking the same view with regard to a search, supposedly supported by exigent circumstances, aimed at finding evidence of running a numbers game).

${ }^{8}$ See J. McGinnis \& W. Foege, Actual Causes of Death in the United States, 270 JAMA 2208, Nov. 10, 1993 (reporting the 100,000 deaths figure). I calculate the innocent bystanders estimate (which of course is just a rough estimate) by adding the deaths from intentional homicides where the killer had been drinking (about 4,000 to 5,000) and drunk driving deaths of people other than the drunk driver (about 5,000); I couldn't find good statistics on other causes of death, such as non-auto accidents caused by drinking. U.S. DeP'T OF JustiCE, BurEAU OF Justice STATISTICS, AlCOHOL AND CRIME 29 (1998) (reporting that in about 25\% of murders and manslaughters, the killer "was drinking at the time of the violent offense"); Centers for Disease Control, WISQARS Injury Mortality Reports, 1999-2001, http://webapp.cdc.gov/sasweb/ncipc/mortrate10_fy.html (reporting that in 19992001, there were about 16,000-20,000 intentional homicides in the U.S. per year); NATIONAL SAFETY COUNCIL, INJURY FACTS 94 (2003) (reporting that in 2001, about 15,000 people were killed in car crashes where someone was drunk, and $33 \%$ of them were passengers or nonintoxicated drivers).

${ }^{9}$ Oklahoma law barred the manufacturing, sale, or importation of virtually all beverages with more than 4\% alcohol. See OKLA. STAT. tit. 37, § 1 (1941) (barring manufacturing or sale of beverages with more than $3.2 \%$ alcohol); id. $\S 32$ (prohibiting possession of more than one gallon of spirits or wine, or one cask of malt liquor); $i d$. at 41 (prohibiting importation of beverages with more than 4\% alcohol). See also Okla. Sess. Laws 1959, at 141; OKLA. Const. art. I, § 7 (1907) (prohibiting distribution of alcohol in the former Indian Territory, a huge part of Oklahoma), repealed by OKLA. CONST. art. XXVII (1959); JiMMIE L. FrANKLIN, BORN SOBER, PROHIBITION IN OKLAHOMA 1907-1959 (1971) (discussing prohibition throughout Oklahoma).

${ }^{10}$ The prohibition was naturally not enforced with great sternness. Selling or manufacturing stronger drinks was punished only as a misdemeanor for the first offense, with a maximum sentence of 6 months in jail, and possession of small amounts of alcohol at home wasn't criminalized, though importation was punished by up to five years in prison. OKLA. STATS. tit. 37, §§ 1, 12 (1951). But I suspect that this just reflected the difficulties of practically enforcing alcohol prohibition, given the magnitude of noncompliance by otherwise law-abiding people. A reasonable legislature may well have concluded both that alcohol was extremely dangerous, and that imprisoning moonshiners and 
not clear what principled way there was for the Court to reject that judgment. ${ }^{11}$

This Essay can't fully answer the two questions I asked at the outset. The answers should probably differ for different constitutional provisions, and should be deduced with an eye towards the attributes of the particular right that's involved. But it does aim to lay out four categories of possible answers, and to briefly outline some of the pluses and minuses of each. (Surprisingly, few works have so far discussed this matter broadly and systematically. ${ }^{12}$ ) I hope this will be helpful to others who come across this recurring problem. And I hope it will at least suggest that two simple answers - that such severity distinctions are always improper, and thatthey are unproblematic_-are mistaken.

\section{OPTION 1: REJECTING SEVERITY DISTINCTIONS}

To begin with, judges could refuse to incorporate crime severity judgments into constitutional rules, precisely because it's so hard to make these determinations in a principled way. ${ }^{13}$ At times, the Court has seemingly asserted this as a constitutional mandate. In Mincey v. Arizona, for instance, the Court declined to create a "murder scene" exception to the Fourth Amendment warrant requirement, reasoning that courts had no manageable standards for drawing a line between murders and other crimes:

[T] he public interest in the investigation of other serious crimes is comparable. If the warrantless search of a homicide scene is reasonable, why not the warrantless search of the scene of a rape, a robbery, or a burglary? "No consideration relevant to the Fourth

illegal vendors for many years would be impractical. $C f$. William A. Schroeder, Factoring the Seriousness of the Offense into the Fourth Amendment Equations-Warrantless Entries into Premises: The Legacy of Welsh v. Wisconsin, 38 KAN. L. REV. 439, 516 (1990) (concluding that relatively lenient treatment for a crime "may not always reflect a cavalier attitude toward the offense," but rather "a feeling that penal sanctions are not always the best solution to a social problem," or "a desire to "increase the ease of conviction and the overall deterrent effect of the enforcement effort,", quoting Welsh v. Wisconsin, 466 U.S. 740, 763 (1989) (White, J., dissenting)).

${ }^{11}$ There is, of course, little problem with legislatures making such judgments, because legislatures are expected to simply apply their moral and pragmatic judgments, even if this means drawing seemingly arbitrary lines. See, e.g., 18 U.S.C. $\S \S 2516(1)$, (2) (amended in part by the USA Patriot Act, 107th Cong., 1st Sess., P.L. 107-56, sec. 201 (2001)) (defining crimes that prosecutors may generally use wiretaps to investigate); 18 PA. CONSOL. STAT. §§ 5708(1), (2) (likewise).

${ }^{12}$ A quick WESTLAW search, for instance, finds few articles that even cite both Branzburg $v$. Hayes and Mincey v. Arizona - the two leading Supreme Court cases that reject severity distinctions in First Amendment and Fourth Amendment cases-and none of them discusses those two cases together. For excellent treatments focused on the Fourth Amendment, see Stuntz, O.J. Simpson, Bill Clinton, and the Transsubstantive Fourth Amendment, supra note 1; Luna, supra note 1, at 778-87; Schroeder, supra note 10.

${ }^{13}$ Cf. Atwater v. City of Lago Vista, 532 U.S. 318, 352 (2000) ("It is of course easier to devise a minor-offense limitation by statute than to derive one through the Constitution, simply because the statute can let the arrest power turn on any sort of political consideration without having to subsume it under a broader principle.”). 
Amendment suggests any point of rational limitation" of such a doctrine. ${ }^{14}$

Likewise, in New Jersey v. T.L.O., the Court allowed searches of public school students based merely on reasonable suspicion, and refused to limit this doctrine to searches for evidence of serious offenses:

We are unwilling to adopt a standard under which the legality of a search is dependent upon a judge's evaluation of the relative importance of various school rules. . . The promulgation of a rule forbidding specified conduct presumably reflects a judgment on the part of school officials that such conduct is destructive of school order or of a proper educational environment. Absent any suggestion that the rule violates some substantive constitutional guarantee, the courts should, as a general matter, defer to that judgment and refrain from attempting to distinguish between rules that are important to the preservation of order in the schools and rules that are not. ${ }^{15}$

And in Branzburg v. Hayes, the Court declined to create a First Amendment journalists' privilege that was sensitive to the severity of the crime being investigated:

[B]y considering whether enforcement of a particular law served a "compelling" governmental interest, the courts would be inextricably involved in distinguishing between the value of enforcing different criminal laws. By requiring testimony from a reporter in investigations involving some crimes but not in others, they would be making a value judgment that a legislature had declined to make, since in each case the criminal law involved would represent a considered legislative judgment, not constitutionally suspect, of what conduct is liable to criminal prosecution. The task of judges, like other officials outside the legislative branch, is not to make the law but to uphold it in accordance with their oaths. ${ }^{16}$

If this is right, then it seems that constitutional rules may never require courts to evaluate the severity of crimes. Any such evaluation requires judges to "distinguish[] between the value of enforcing different criminal laws," to "mak[e] a value judgment that a legislature had declined to make," and to draw distinctions analogous to those between murder and rape, robbery, and burglary.

14437 U.S. 385, 393 (1978). See also Florida v. J.L., 529 U.S. 266, 272 (2000) (refusing to create a special rule based on anonymous tips that someone has a weapon, partly because "one [could not] securely confine such an exception to allegations involving firearms," though noting that there might be a special exemption where "the danger alleged in an anonymous tip might be so great as to justify a search even without a showing of reliability," for instance when there is "a report of a person carrying a bomb"); Richards v. Wisconsin, 520 U.S. 385, 393-94 (1997) (refusing to categorically exclude drug crimes from the requirement that police knock and announce themselves when performing a search, unless exigent circumstances are present, because "the reasons for creating an exception in one category can, relatively easily, be applied to others"; "[i]f a per se exception were allowed for each category of criminal investigation that included a considerable-albeit hypothetical-risk of danger to officers or destruction of evidence, the knock-and-announce element of the Fourth Amendment's reasonableness requirement would be meaningless"); Chimel v. California, 395 U.S. 752, 766 (1969) (insisting that decisions about the permissible scope of searches incident to arrest be based on "reasoned distinctions," rather than arbitrary line-drawing based on the size of the area to be searched).

${ }^{15}$ New Jersey v. T.L.O., 469 U.S. 325, 342 n.9 (1985).

${ }^{16} 408$ U.S. 665, 705 (1972). 
Refusing to consider crime severity would avoid such hard-to-defend judgments about how important various laws are, and would also yield rules that are easier to apply. The Court can, for instance, announce that there may be no warrantless searches of people's homes (subject to a few exceptions, such as exigent circumstances), with no need for often controversial and unpredictable case-by-case decisions about which crimes are serious enough to justify a "crime scene exception."

Many constitutional doctrines are indeed not relaxed, at least officially, when the crime is especially severe. The case against relaxing the constitutional rules is especially strong for provisions at least partly aimed at making factfinding more accurate. The more severe the crime, the more we also want to convict the guilty, but the more we want to prevent convicting the innocent as well. ${ }^{17}$ Lowering the "beyond a reasonable doubt" standard, for instance, in murder cases would help deter an especially serious sort of crime, but only at the expense of correspondingly increasing the number of especially serious wrongful convictions. And even for the First and Fourth Amendments, where the increasing strength of the government interest isn't generally matched by corresponding increases in the strength of the private interest, ${ }^{18}$ courts have generally not drawn any explicit severity distinctions. ${ }^{19}$

Yet this refusal to draw severity distinctions has obvious costs: It may constrain the government too much when it fights very serious crimes, and too little when it fights minor ones. The Fourth Amendment prohibits "unreasonable searches and seizures," and in our daily lives we judge the reasonableness of a reaction in part based on the harm that it aims to avoid. It seems appealing to have constitutional law do likewise. Similarly, First Amendment law often asks whether a government

${ }^{17}$ Cf. Craig v. Maryland, 497 U.S. 836, 867-68 (1990) (Scalia, J., dissenting) (pointing out that the interest in preventing wrongful convictions is especially strong when the "innocent defendants [are] accused of particularly heinous crimes").

${ }^{18}$ The free speech interest in describing how to kill, for instance, isn't greater than the free speech interest in describing how to infringe copyright. See generally Eugene Volokh, Crime-Facilitating Speech pt. I (circulated for publication) (discussing restrictions on both kinds of speech).

Luna, supra note 1, at 785, argues that Fourth Amendment rules shouldn't turn on crime severity, partly because a crime's seriousness "does not allow the state to circumvent or even relax other constitutional rights, such as the reasonable doubt standard or the right to trial by jury." But for the reasons given in the text, severity distinctions may be more apt for the First and Fourth Amendments than for the other rights.

${ }^{19}$ See, e.g., Mincey; Branzburg; T.L.O.; Dunaway v. New York, 442 U.S. 200, 213-14 \& nn.1314 (1979) (rejecting a balancing test that would allow detentions with less than probable cause based in part on "the gravity of the crime involved"). See also Stuntz, Local Policing After the Terror, supra note 6, at 2140 (noting that "most constitutional limits on policing are transsubstantive-they apply equally to suspected drug dealers and suspected terrorists," and "there is no reason to believe that current exigencies will change it"); Silas J. Wasserstrom, The Court's Turn Toward a General Reasonableness Interpretation of the Fourth Amendment, 27 AM. CRIM. L. REV. 119, 137 (1989) (asserting that Welsh v. Wisconsin, 466 U.S. 740 (1989), was "the first Supreme Court case to hold that the gravity of the underlying offense is relevant to any important fourth amendment issue, at least where a full scale search or seizure is involved"). 
inte est is "compelling." Presumably the interest in prosecuting some crimes is compelling, while the interest in prosecuting others isn't.

And these costs have indeed led the courts to rely on constitutional severity distinctions, often without much discussion or even controversy. Consider, for instance, the child pornography exception to the First Amendment. Production of child pornography, the Court pointed out, is illegal, because it inherently involves the sexual exploitation of children. Therefore, to deter this production, and to mitigate the harm that the production causes, the government may ban the distribution and even the possession of such material-even by people who aren't directly conspiring with the producers - as well as the production itself. ${ }^{20}$

If the severity of the crime that the law is fighting is indeed constitutionally irrelevant, then the same logic would presumably allow other kinds of speech restrictions defended on a similar "deter the illegal production / illegal initial release" theory. The government could, simply by citing the child pornography cases, justify bans on publishing news stories that are based on corporate secrets, trade secrets, or government secrets that some insider illegally leaked to the newspaper. ${ }^{21}$ It could justify bans on publishing cell phone conversations that were illegally recorded and sent anonymously to the media. ${ }^{22}$ And it could justify bans on publishing photographs or movies that depict actual animal cruelty. ${ }^{23}$

I doubt, though, thatthe Court would or should accept such restrictions simply by analogy to the child pornography cases Those cases explicitly relied on sexual exploitation of children being such a serious crime, ${ }^{24}$ serious enough to justify banning speech based on the fruits of the crime. But when the speech springs from a lesser offense (such as an illegal leak), the need to deter the offense is less pressing, and the case for protecting speech is greater.

One can, of course, try to distinguish child pornography on other grounds, for instance based on the perceived difference in the value of the speech (though that

${ }^{20}$ New York v. Ferber, 458 U.S. 747, 759 (1982); Osborne v. Ohio, 495 U.S. 103, 110-11 (1990).

21 See Eugene Volokh, Freedom of Speech and Intellectual Property: Some Thoughts After Eldred, 44 Liquormart, and Bartnicki, 40 Hous. L. REV. 697, 739-48 (2003) (discussing these restrictions).

${ }^{22}$ See Bartnicki v. Vopper, 532 U.S. 514 (2001) (holding such publication to be constitutionally protected, at least in many instances).

${ }^{23}$ Cf. 18 U.S.C. $\$ 48$, which does ban the distribution of videos or photos that depict animal cruelty, but is at least limited-unlike child pornography law-to material that lacks serious value. If severity doesn't matter, then Congress could enact an even broader law, which applied even to valuable depictions.

${ }^{24}$ New York v. Ferber, 458 U.S. 747, 757 (1982); Osborne v. Ohio, 495 U.S. 103, 110 (1990). See Bartnicki, 532 U.S. at 533 (holding unconstitutional, as applied, a statute that banned distribution of material that was drawn from an illegally intercepted telephone call). Likewise, one distinction the Court gave when holding that private possession of child pornography was punishable, though private possession of simple obscenity was not, was that creation and further distribution of child pornography - the harmful conduct that legal possession tends to foster-are more harmful than the distribution of obscenity. Osborne, 495 U.S. at 110. 
itself is a troublesome judgment for courts to make) ${ }_{26}^{25}$ or on the perceived difference in how hard it is to catch the producers themselves. ${ }^{26}$ But it seems to me that courts also should and would focus, as the child pornography cases themselves did, on the severity of the crime, and view the child pornography cases as a narrow exception limited to speech that involved truly grave crimes in its creation. And in fact, the one situation in which courts might be most likely to ban publication of criminally leaked material-newspapers' publishing extraordinarily damaging leaked military secrets ${ }^{27}$-is also the situation where the underlying crime seems to be most severe.

Likewise, consider the question whether shooting a fleeing suspect is an unconstitutional seizure. ${ }^{28}$ The Court has held that it's reasonable to shoot a fleeing suspect when the police have probable cause to believe that he's a murderer; the risks to the murderer's potential future victims are otherwise just too great. ${ }^{29}$

But it seems unreasonable to shoot a fleeing suspect simply because he's a shoplifter or a marijuana user - the pressing concern about public safety that justified the decision to allow shooting at the fleeing murder suspect is absent. If we want both to avoid paralyzing the police officers faced with the really dangerous criminals, and to avoid letting police officers kill even minor criminals, some severity determinations are required.

\section{OPtion 2: Distinguishing SEVERITy Using Rules That TURN ON THE CRIME’s OBJECTIVE CHARACTERISTICS}

Judges could try to create rules distinguishing offenses based on the inherent characteristics of the crime, such as whether the crime involves violence The Court in Tennessee v. Garner, for instance, held that the Fourth Amendment generally bars the police from shooting at a fleeing felon unless "the suspect threatens the officer with a weapon or there is probable cause to believe that he has committed a crime involving the infliction or threatened infliction of serious physical harm." "30 Though "burglary is a serious crime," the Court concluded, "it is [not] so dangerous as automatically to justify the use of deadly force," because it is "a "property' rather

${ }^{25}$ See Bartnicki, 532 U.S. at 530 n.13 (stressing the "minimal value" of the child pornography at issue in Ferber).

${ }^{26}$ Compare id. at 530-31 (arguing that in most cases where an illegally intercepted conversation is published, the identity of the interceptor himself will be known, though acknowledging that in some unusual cases, it will not be) with id. at 549 (Rehnquist, C.J., dissenting) (arguing, in my view more plausibly, that the identity of the interceptor may often be unknown).

${ }^{27}$ Cf. New York Times Co. v. United States, 403 U.S. 713, 735-40 (1971) (White, J., concurring in the judgment, joined by Stewart, J.) (suggesting that such publication might well be criminally pn ishable); id. at 752-59 (Harlan, J., dissenting, joined by Burger, C.J., and Blackmun, J.) (concluding that such publication could even be enjoined).

${ }^{28}$ Tennessee v. Garner, 471 U.S. 1, 11 (1985).

${ }^{29} \mathrm{Id}$. at $11-12$.

${ }^{30} \mathrm{Id}$. at 11 . 
than a 'violent' crime."31

Similarly, Coker v. Georgia held that the death penalty was an excessive punishment for the rape of an adult, because "in terms of moral depravity and of the injury to the person and to the public, [rape] does not compare with murder, which . . . involve[s] the unjustified taking of human life."32 It's possible that the death penalty may still be available for child rape and for very serious national security crimes such as treason and espionage. ${ }^{33}$ But the Court must have understood Coker as effectively limiting the death penalty almost exclusively to murder prosecutions, which is how it has indeed been in practice applied. And this limitation reflects a fairly clear and coherent (though not uncontroversial ${ }^{34}$ ) rule that the infliction of death should be reserved largely for those who themselves inflict death.

There are, however, three problems with this sort of line-drawing. First, only a few fairly clear lines are available. The distinctions between violent crimes and property crimes, victimless crimes and other crimes, reckless conduct and negligent conduct, negligent conduct and nonnegligent conduct, and murder and other crimes are possibilities; but few others come to mind. ${ }^{35}$

If one thinks that the constitutional rule should track one of these lines, the limited set of lines isn't a problem. But if one thinks, for instance, that speakers should be free to incite minor property crimes but not severe ones, ${ }^{36}$ or that they should be free to publish books that reveal ways to kill someone (for instance, detective stories that describe ingenious murder methods) but not books that reveal ways to kill thousands of people at once, ${ }^{37}$ then one might not be able to find any place to draw a sharp line.

Second, even these supposedly sharp distinctions aren't always so sharp. For instance, there are bitter disagreements about what constitutes a victimless crime. To

${ }^{31}$ Id. at 21. See also State Farm Mutual Automobile Ins. v. Campbell, 123 S. Ct. 1513, 1521 (2003) (holding that the Due Process Clause limits the amount of punitive damages, and that one factor in this limitation was the gravity of the defendant's misconduct, determined based on factors such as whether "the harm caused was physical as opposed to economic").

32433 U.S. 584, 598 (1977).

33 See, e.g., State v. Wilson, 685 So. 2d 1063 (La. 1996) (child rape); 10 U.S.C. § 906a (espionage) (enacted 1985).

${ }^{34}$ See Coker, 433 U.S. at 607-13 (Burger, C.J., dissenting).

35 Schroeder, supra note 10, at 520, also discusses possible distinctions between malum prohibitum and malum in se crimes, and between crimes that involve moral turpitude and crimes that don't. Both these distinctions, though, are rather vague, see Jordan v. De George, 341 U.S. 223, 236 (1951); Schroeder, supra note 10, at 521 (moral turpitude), and they also don't correlate particularly well with seriousness: Shoplifting, for instance, is malum in se and involves moral turpitude. See Johnson v. State, 291 So. 2d 336 (Ala. 1974) (theft involves moral turpitude).

${ }^{36}$ Cf. Whitney v. California, 274 U.S. 357, 378 (1927) (Brandeis, J., concurring in the judgment).

37 See Volokh, Crime-Facilitating Speech, supra note 18, pt. V.C (taking this view); United States v. Progressive, Inc., 486 F. Supp. 5 (W.D. Wis. 1979) (enjoining the publication of article describing how a hydrogen bomb could be constructed), appeal dismissed, 610 F.2d 819 (7th Cir. 1979). 
some, drug dealing is a victimless crime. To others, drug crimes have many victims (even setting aside the victims caused by the criminalization of drugs) - minors who start using drugs even though they lack the maturity to weigh the risks, people who are killed by intoxicated drivers, and so on. In Harmelin v. Michigan, for instance, Justice Kennedy's concurrence concluded that possessing 650 grams of cocaine was a serious enough crime to justify life imprisonment, and that "[p]etitioner's suggestion that his crime was nonviolent and victimless, echoed by the dissent, is false to the point of absurdity. To the contrary, petitioner's crime threatened to cause grave harm to society." 38 And more generally, most supposedly victimless crimes were criminalized because many people thought that the crimes did victimize someone, though perhaps indirectly.

The distinction between violent crimes and property crimes is less controversial in many cases; at least it's clear that some crimes are genuinely merely property crimes. But again, how does one classify drug crimes, which don't inherently involve any outright violence, but do involve the risk of physical injury or even death to the drug users or to others? ${ }^{39}$ How does one classify residential burglary, which involves some risk of violence, though probably less than armed robbery does, and which also gravely undermines the victims' sense of privacy and security? ${ }^{40}$ How does one classify illegal gun possession?

Third, even the sharp distinctions may be quite controversial. ${ }^{41}$ Murder may be

38501 U.S. 957, 1002 (1991) (Kennedy, J., concurring in the judgment). But see Schroeder, supra note 10, at 524 (viewing the distinction between victimless crimes and other crimes more favorably).

${ }^{39}$ Compare United States v. Soyka, 394 F.2d 443, 452 (2d Cir. 1968) (Friendly, J., dissenting) ("If my brothers' ruling could be confined to narcotics pushers like Aguilar and Soyka or gamblers like Riggan, I would hardly dissent [from the decision excluding certain evidence as having been go ten in violation of the Fourth Amendment]. But that is not the received wisdom of today; at least in theory this decision would govern crimes of the greatest seriousness and cases where an arrest might lead to the recovery of stolen property or even a kidnapped child rather than of contraband.") and Commonwealth v. Hamilton, 508 N.E.2d 870, 872-73 (Mass. Ct. App. 1987) (holding that the Fourth Amendment barred a warrantless entry into a home for the purposes of arresting a resident, even when exigent circumstances were present, partly because possessing cocaine or heroin wasn't a crime of violence) with Schroeder, supra note 1, at 531 (citing those two cases, but responding that "one could argue that the drug trade is so intimately bound up in violence that it is, in effect, a violent crime").

${ }^{40}$ See People v. Weaver, 161 Cal. App. 3d 119, 127 (1984) (reasoning that "[r]esidential burglary is an extremely serious crime presenting a high degree of danger to society," because of "the danger that the intruder will harm the occupants in attempting to perpetrate the intended crime or to escape and the danger that the occupants will in anger or panic react violently to the invasion, thereby inviting more violence," and because residential burglary "involves an invasion of perhaps the most secret zone of privacy") (internal quotation marks and citations omitted).

${ }^{41} C f$. Blanton v. City of North Las Vegas, 489 U.S. 538, 541 \& n.5 (1989) (opining that on such matters "the judiciary should not substitute its judgment as to seriousness for that of a legislature, which is far better equipped to perform the task, and [is] likewise more responsive to changes in attitude and more amenable to the recognition and correction of their misperceptions in this respect") (internal quotation marks and citations omitted). 
more heinous than adult rape or child rape, but is it so qualitatively different that the Eighth Amendment should preclude the death penalty for the latter two crimes? ${ }^{42}$ How can one rebut, in a principled way, those who say that child rape is so evil and harmful that it ought to be treated like murder rather than like robbery?

So such lines may give the government more power to use harsh methods against serious crimes without providing the same power for all crimes. And the lines may provide this power while decreasing the need for courts to subjectively decide, in case after case, just how s rious the judges find a particular crime to be.

But the lines will require at least some subjective decisionmaking when drawing the line up front. They will probably require some such decisionmaking even in later cases, when the line proves not to be perfectly crisp and objective. And they may limit courts to only a narrow set of available severity distinctions.

\section{Option 3: Distinguishing SeVERity Using Rules That TuRn On The LEGISLATURE'S OWN CATEGORIZATION OF THE CRIME}

Judges could also create rules that distinguish offenses based on the legislature's own categorizations, such as whether the offense is a crime or just a tort, whether it's a felony or a misdemeanor, whether it can lead to jail time, or how much jail time it can lead to.

For instance, the Supreme Court has taken the view that the criminal jury trial right was originally understood not to apply to "petty crimes." What, then, is a petty crime? The Court acknowledged, in Duncan v. Louisiana, that "the boundaries of the petty offense category have always been ill-defined," but concluded that "[i]n the absence of an explicit constitutional provision, the definitional task necessarily falls on the courts. ... [ [I]t is necessary to draw a line in the spectrum of crime, separating petty from serious infractions."43

This line, the Court had earlier held, should be drawn "not subjectively by recourse of the judge to his own sympathy and emotions, but by objective standards such as may be observed in the laws and practices of the community taken as a gauge of its social and ethical judgments." 44 And because the general practice

${ }^{42}$ See, e.g., State v. Wilson, 685 So. 2d 1063 (La. 1996) (holding that people who rape children may be sentenced to death, because child rape is a more severe crime than rape); Sherry Colb, FINDLAW.COM WRIT, Is Capital Punishment Too Harsh for Rapists?, Sept. 10, 2003, available at http://writ.corporate.findlaw.com/colb/20030910.html ("It is arbitrary . . . to treat child rape as qualitatively more heinous than the 'rape of an adult woman,' for death penalty purposes. To do so minimizes the devastation of rape for women, because it suggests that although the rape of one category of people is bad enough to call for execution, adult women do not qualify - as a matter of constitutional law-for inclusion in that category.").

${ }^{43}$ Duncan v. Louisiana, 391 U.S. 145, 160-61 (1968).

${ }^{44}$ District of Columbia v. Clawans, 300 U.S. 617, 628 (1937); see also Duncan, 391 U.S. at 161 (concluding that the line should be drawn by "refer[ring] to objective criteria, chiefly the existing laws and practices in the Nation," citing Clawans); Baldwin v. New York, 399 U.S. 66, 68-69 (1970) 
throughout the country seems to have been to distinguish offenses with maximum jail terms of six months or less from offenses with longer maximum terms, ${ }^{45}$ the Court has more or less settld on this as the constitutional di stinction.

Likewise, in Welsh v. Wisconsin, the Court held that a warrantless home arrest couldn't be justified by the Fourth Amendment's exigent circumstances exception when the person was being arrested for a nonjailable misdemeanor. The misdemeanor was drunk driving, which at least one member of the majority thought was very dangerous. ${ }^{46}$ Still, the Court concluded that Wisconsin's classifying the misdemeanor as a nonjailable offense was "the best indication of the State's interest in precipitating an arrest, and is one that can be easily identified both by the courts and by officers faced with a decision to arrest." $" 47$

The severity distinction in Welsh differs from the one in Duncan: In Welsh and in the other cases I discuss in this Essay, the severity of the crime cut in favor of weaker constitutional protection, while in Duncan it cut in favor of stronger protection. Still, the core question is similar: When some factor-constitutional text ("reasonable[ness]" in Welsh), constitutional history (the acceptance, from the late 1700 s to the present, of trials without jury for petty offenses), ${ }^{48}$ or felt necessity (the compelling interest exception to free speech protection ${ }^{49}$ )—suggests some distinction between more and less serious crimes, how are courts to draw this distinction? The Court's answer in these cases is to piggyback on legislative line-drawing.

This approach lets courts create lines that are quite sharp; and it can let judges avoid entirely substituting their views for legislators' views, since they can point to

(likewise).

${ }^{45}$ Duncan, 391 U.S. at $161 \&$ n.33. The Court has also held that the right to appointed counsel applies only when the defendant faces actual jail time. Argersinger v. Hamlin, 407 U.S. 25 (1972). The justification for this distinction, though, rested on severity of the specific punishment (imprisonment) that the defendant faced, not on the severity of the crime: The defendant may, for instance, be prosecuted without appointed counsel even for a crime that is theoretically punishable by some prison time, if the judge simply announces that he will not impose any prison sentence even if the defendant is found guilty. All that the Court had to decide, then, is that the risk of loss of liberty justifies a certain procedural protection-the Justices didn't actually have to draw distinctions between different categories of offense.

46466 U.S. 740,752 (1984).

${ }^{47}$ Id. at 754. See also Atwater v. City of Lago Vista, 532 U.S. 318, 365 (2001) (O'Connor, J., dissenting) (arguing that it should be unconstitutional to arrest a person for a nonjailable offense, absent special circumstances, because "If the State has decided that a fine, and not imprisonment, is the appropriate punishment for an offense, the State's interest in taking a person suspected of committing that offense into custody is surely limited, at best."); State v. Jones, 727 N.E.2d 886, 893 (Ohio 2000) (adopting such a rule), reaffirmed in relevant part, State v. Brown, 792 N.E.2d 175, 179 (Ohio 2003) (reaffirming the rule under the Ohio Constitution, notwithstanding Atwater); State v. Bauer, 36 P.3d 892, II 33 (Mont. 2001) (adopting such a rule under the Montana Constitution).

${ }^{48}$ See Felix Frankfurter \& Thomas G. Corcoran, Petty Federal Offenses and the Constitutional Guaranty of Trial by Jury, 39 HARV. L. REV. 917 (1926).

49 See Eugene Volokh, Freedom of Speech, Permissible Tailoring and Transcending Strict Scrutiny, 144 U. PA. L. REV. 2417 (1997). 
legislative judgments that themselves acknowledge that certain crimes aren't very serious. After all, if the legislature didn't think some offense was worth making a felony, how can the government argue that the offense is serious enough to justify special relaxation of Fourth Amendment rules? ${ }^{50}$

But here too courts will find few places in which they can draw the line. The lines between crimes and torts, jailable and nonjailable offenses, and felonies and misdemeanors are reasonable candidates. ${ }^{51}$ Occasionally, when validating existing practices, courts may also rely on a longstanding legislative tradition supporting some line; such a tradition seemingly existed for the six-month distinction between petty offenses and serious ones as to the right to jury trial. ${ }^{52}$ When courts are looking for a place to draw a relatively novel line, though, they'll have few existing options to use.

Serious felonies and minor felonies, for instance, can't easily be distinguished, unless courts start drawing rather arbitrary distinctions based on the maximum length of the prison term. ${ }^{53}$ Distribution of child pornography and of newspaper articles based on material that someone leaked in violation of a felony trade secret law would have to be treated equally. So would the fleeing killer and the fleeing thief of products that are worth more than the felony theft threshold.

Moreover, when severity leads to less constitutional protection, the legislature would often be able to easily get that lowering of protection just by upgrading the offense. Say, for instance, that the Fourth Amendment prevents the police from using certain search techniques for nonjailable offenses, or that the First Amendment prevents grand juries from subpoenaing reporters to get information about the

${ }^{50}$ But see Schroeder, supra note 10 (concluding that relatively lenient treatment for a crime "may not always reflect a cavalier attitude toward the offense," but rather "a feeling that penal sanctions are not always the best solution to a social problem," or "a desire to "increase the ease of conviction and the overall deterrent effect of the enforcement effort," quoting Welsh, 466 U.S. at 763 (White, J., dissenting)).

${ }^{51}$ But see Schroeder, supra note 10, at 508-09 (criticizing the felony/misdemeanor line, because "[i]n many jurisdictions the same conduct can be either a misdemeanor or felony depending on how it is prosecuted or depending on the institution to which the offender is sentenced," and because "numerous misdemeanors involve conduct more dangerous than many felonies") (internal quotation marks omitted). The line between capital and noncapital offenses might have been plausible in the past, see United States v. Salerno, 481 U.S. 739, 753 (1987) (discussing this as a dividing line for the right to bail); but today is itself more a judicially determined line, defined by the Court's death penalty caselaw, rather than a legislatively determined one.

${ }^{52}$ See Baldwin v. New York, 399 U.S. 66, 70 (1970) (selecting six months as the dividing line because "with a few exceptions, crimes triable without a jury in the American States were . . . generally punishable by no more than a six-month prison term," and because when an earlier case on the subject was decided two years before, "we could discover only three instances in which a State denied jury trial for a crime punishable by imprisonment for longer than six months").

53 The misdemeanor/felony line may also turn in many states on the length of the permissible prison term, but at least it's a line that has long historical significance, considerable collateral legal consequences - such as, in many states, place of incarceration, denial of the right to possess guns even after one is freed, and loss of the right to vote_-and considerable reputational consequences. 
commission of misdemeanors. The legislature can just upgrade the offense into a felony, but provide enough alternative charges or sentences so that the prosecutor can investigate the crime as a felony but prosecute it as a nonjailable misdemeanor, or so that a judge can routinely suspend any prison sentence. ${ }^{54}$

There might be some political opposition to upgrading torts to crimes, or to seriously upgrading petty crimes that many people commit, such as minor traffic offenses. But it's not clear how much opposition there would be: Consider, for instance, many states' authorization of custodial arrests even for traffic offenses, when the traffic offenses are treated as criminal infractions. ${ }^{55}$ So by and large, any severity distinctions that turn on the legislature's own characterization of the crime won't much constrain the government: The "severe crimes" zone will be reached at a rather low level, and the legislature should find it fairly easy to move even petty offenses into that zone.

\section{Option 4: Distinguishing Severity Based on CASE-By-Case EVALUATION}

Finally, judges may decide case by case which offenses are serious enough and which aren't. That apparently happened with the First Amendment child pornography exception, which was based partly on the conclusion that sexual exploitation of children is such a serious crime. ${ }^{56}$ The Court's Cruel and Unusual Punishments Clause cases have likewise held - though over strong disagreementthat courts must determine the propriety of sentences partly by evaluating, case by case, the severity of the crimes. ${ }^{57}$ The Excessive Fines Clause caselaw requires

${ }^{54}$ See Schroeder, supra note 10, at 509, 517 (making this point); id. at 517 (noting that this may be unlikely when relatively little extra government power is at stake). Of course, when severity means more constitutional protection, as with the right to trial by jury, the legislature may have less flexibility, because lowering the maximum sentence will constrain prosecutors and judges more than lowering the minimum sentence would.

55 See Atwater v. City of Lago Vista, 532 U.S. 318, 355-58 (2001); Wayne A. Logan, Street Legal: The Court Affords Police Constitutional Carte Blanche, 77 IND. L.J. 419, $429-49$ (2002) (arguing that such arrests are not uncommon, and aren't likely to be statutorily restrained); Michele Deitch, Veto Risks Texans' Civil Rights, Dallas MoRning News, July 1, 2001, at 5J (noting that the Texas governor vetoed a bill that would have generally barred warrantless arrests for petty traffic offenses); Texas Legislature, Actions: Bill: SB 730-Legislative Session: 77(R), http://www.capitol.state.tx.us/cgi-

bin/db2www/tlo/billhist/actions.d2w/report? $L E G=77 \& S E S S=R \& C H A M B E R=S \& B I L L T Y P E=B \& B I L$ $L S U F F I X=00730 \& S O R T=A s c$ (confirming veto).

${ }_{57}^{56}$ See supra text accompanying notes $24-27$.

57 See, e.g., Ewing v. California, 538 U.S. 11, 20-24 (2003) (reaffirming the case-by case approach); id. at 31-32 (Scalia, J., concurring in the judgment) (rejecting such an approach). The test is actually a three-prong test, which requires courts to consider first "(i) the gravity of the offense and the harshness of the penalty," and then in "the rare case in which a threshold comparison of the crime committed and the sentence imposed leads to an inference of gross disproportionality," also compare the sentence with "(ii) the sentences imposed on other criminals in the same jurisdiction; and (iii) the 
courts to judge the magnitude of a fine in light of its severity. ${ }^{58}$ And, similarly, the Court has held that the government must show an "overriding justification" to force defendants to take antipsychotic drugs in order to become competent to stand trial, and that an accusation of "serious crime" would provide such a justification. ${ }^{59}$

This approach seems appealing, precisely because it lets courts decide in each case how severe a crime is, without having to rely on bright lines that might not perfectly fit judges' sense of crime severity. There are three main difficulties, though, with this approach.

First, it creates a good deal of uncertainty, both for government officials and for citizens. May police officers engage in warrantless searches of cars suspected to contain smuggled alcohol, smuggled marijuana, or smuggled counterfeit products ${ }^{60}$ What sentence may a judge constitutionally impose on someone who has been convicted of this particular crime, and has this particular criminal history? May the legislature outlaw incitement of trespass on unenclosed land, to borrow Justice Brandeis's example? ${ }^{61}$ May it outlaw communications that facilitate relatively minor

sentences imposed for commission of the same crime in other jurisdictions." $I d$. at 22,30 . The second and third factors are more akin to an evaluation based on legislative categorizations of the crime (see supra Part IV), though they may also look to decisions made by other sentencing judges; only the first factor thus properly fits in this Part. Nonetheless, as the Court pointed out, it is only "the rare case" in which courts must go beyond the first factor to the second and the third.

${ }^{58}$ See, e.g., United States v. Bajakajian, 524 U.S. 321 (1998).

${ }^{59}$ Sell v. United States, 123 S. Ct. 2174,2184 (2003). The Court's Fourth Amendment "special needs" case at times stress the harmfulness of the conduct that the search or seizure is trying to uncover. See, e.g., Michigan Dep't of State Police v. Sitz, 496 U.S. 444, 451 (1990) (stressing, in upholding checkpoints aimed at catching and deterring drunk drivers, "the magnitude of the drunken driving problem" and "the States' interest in eradicating it"); Skinner v. Railway Labor Executives' Ass'n, 489 U.S. 602, 633 (1989) (stressing the "compelling Government interests served by" a drug and alcohol testing program for railway employees involved in certain train accidents). It's not clear, though, how significant a role this factor plays, or when the Court would conclude that the need is not great enough. In Delaware v. Prouse, 440 U.S. 648 (1979), for instance, the Court suggested that checkpoints might be permitted even to check to make sure people aren't driving without a license or a registration. Id. at 663. Likewise, in New Jersey v. T.L.O., 469 U.S. 325 (1985), the Court used a "special needs" rationale to allow searches of public schools students based merely on "reasonable suspicion," and explicitly rejected the view that "some rules regarding student conduct are by nature too 'trivial' to justify a search based upon reasonable suspicion." Id. at 342 n.9.

Conversely, in City of Indianapolis v. Edmond, 531 U.S. 32 (2000), and Ferguson v. City of Charleston, 523 U.S. 67 (2001), the Court struck down drug checkpoints and the testing of obstetrics patients for drugs, because these programs were aimed at advancing "the general interest in crime control," 531 U.S. at 44; 532 U.S. at 81, even though the crime that they were trying to control was quite serious, likely as serious as drunk driving. The Court's special needs cases today thus seem focused primarily on whether the searches and seizures are aimed at some interest other than crime control, on how intrusive they are, and on how much discretion they leave to the police-the seriousness of the crime being detected or deterred seems to be less significant.

${ }^{60}$ Cf. Brinegar v. United States, 338 U.S. 160, 183 (1948) (Jackson, J., dissenting) (alcohol smuggling).

${ }^{61}$ Whitney v. California, 274 U.S. 357, 378 (1927) (Brandeis, J., concurring in the judgment). 
crimes, such as drivers' alerting other drivers about a speed trap, or newspaper reporters' informing people about Web sites that contain copyright-infringing mae rial $?^{62}$

Conversely, may speakers feel free to engage in such incitement or crimefacilitating speech? If the only announced rule is that the speech restriction is permitted for speech that urges or aids "serious" crimes but not "less serious" crimes, then people can't know what they're allowed to say, at least until courts in this particular jurisdiction set a square precedent related to this particular offense.

Second, the approach requires courts to repeatedly draw distinctions that are hard to explain using any constitutional principle. This need not be a fatal objection: Perhaps so long as there is a constitutional principle that shows the need to draw a line somewhere, courts should feel free to draw such a line even if they can't explain the principle underlying their decision to draw it in a particular place. ${ }^{63}$

Nonetheless, neither is it an empty objection. Judgments about a crime's severity are often hotly contested. How seriously one should treat drug abuse, illegal gun carrying, blocking of abortion clinic entrances, drunk driving, and similar crimes are questions that have no logically provable answer.

Legislators can draw distinctions based simply on their own moral judgments, or their constituents' moral judgments. ${ }^{64}$ But judges, and especially unelected federal judges, derive much of their credibility from the perception that they're doing something different than just applying their own moral judgments. And turning each crime severity distinction into a constitutional issue - an issue on which the judge's decision will trump the legislator's decision —will highlight the arbitrariness of the judges' choice, not just once when a general rule is created but each time a case arises.

Third, because an ad hoc approach requires courts to make repeated decisions that are controversial, that set aside legislative judgments about severity, and that do so without any seeming application of a principle, some judges - not all, but some-

${ }^{62}$ See Volokh, Crime-Facilitating Speech, supra note 18, at pt. I (citing examples of such speech, and of the laws under which it might be restricted).

${ }^{63}$ See, e.g., Duncan v. Louisiana, 391 U.S. 145, 160-61 (1968) ("In the absence of an explicit constitutional provision [explaining which crimes are so petty that they don't require a jury trial], the definitional task necessarily falls on the courts. . . . [I]t is necessary to draw a line in the spectrum of crime, separating petty from serious infractions. This process, although essential, cannot be wholly satisfactory, for it requires attaching different consequences to events which, when they lie near the line, actually differ very little.”); County of Riverside v. McLaughlin, 500 U.S. 44 (1991) (“Our task in this case is to articulate more clearly the boundaries of what [delay before determination of probable cause following a warrantless arrest] is permissible under the Fourth Amendment. Although we hesitate to announce that the Constitution compels a specific time limit, it is important to provide some degree of certainty so that States and counties may establish procedures with confidence that they fall within constitutional bounds. Taking into account the competing interests articulated in [an earlier case], we believe that a jurisdiction that provides judicial determinations of probable cause within 48 hours of arrest will, as a general matter, comply with the promptness requirement ....").

${ }^{64}$ See, e.g., examples cited supra in note 11. 
may feel obliged to defer to the legislative judgments even while purporting to review those judgments. ${ }^{65}$ Such decisionmaking will thus tend to lead courts to ultimately define the gravity threshold at a pretty low level. Some examples:

1. In Riggins v. Nevada, the Court held that criminal defendants may not be forced to take antipsychotic drugs in order to become competent to stand trial, unless there is "overriding justification." 66 A decade later, in Sell v. United States, the Court interpreted this as requiring that "important governmental interests [be] at stake," and concluded that this test was satisfied if the defendant is "accused of a serious crime." ${ }^{67}$ But the Court then held that an "important" interest is present "whether the offense is a serious crime against the person or a serious crime against property," because "[i]n both instances the Government seeks to protect through application of the criminal law the basic human need for security." ${ }^{, 68}$ This may well be the right result, but it does show judges' reluctance to dismiss some crimes, even nonviolent crimes, as too petty to pass the severity threshold. ${ }^{69}$

2. In cases where defendants invoke the Cruel and Unusual Punishments Clause

${ }^{65}$ See, e.g., Part II, which described Supreme Court decisions that purported to categorically reject any such ad hoc decisionmaking. I argue in the rest of this Essay that judges haven't always been so reluctant to draw such lines, and that perhaps they shouldn't be so reluctant. But the cases in Part II show that at least some judges are reluctant to exercise their power to draw constitutionality severity lines.

${ }^{66} 504$ U.S. 127, 135 (1992).

${ }^{67} 123$ S. Ct. 2174, 2184 (2003).

${ }^{68} \mathrm{Id}$. The "compelling government interest" prong of the First Amendment strict scrutiny test may seem like an authorization for the Court to distinguish the exceptionally strong government interests from the weaker ones. In practice, though, the Court has not been willing to use this prong this way: The Court has found compelling interests not just in preventing violence or injury to national security, but also in shielding children from purely psychological harm caused by exposure to sexual material, in preventing political corruption, in "eliminating from the political process the corrosive effect of political "war chests' amassed with the aid of the legal advantages given to corporations," and in ensuring that "criminals do not profit from their crimes" and that crime victims are compensated by the criminals. Sable Communications v. FCC, 492 U.S. 115, 126 (1989); Buckley v. Valeo, 424 U.S. 1 (1976); Austin v. Michigan Chamber of Commerce, 494 U.S. 652, 666 (1990); Simon \& Schuster, Inc. v. Members of the N.Y. State Crime Victims Bd., 502 U.S. 105, 118 19 (1991). The strict scrutiny test has proven "strict in theory, fatal in fact," because the Court has applied the test's narrow tailoring prong in a demanding way, not because of the compelling interest prong. See Volokh, Freedom of Speech, Permissible Tailoring and Transcending Strict Scrutiny, supra note 49, at 2420-22; Gerald Gunther, The Supreme Court, 1971 Term-Foreword: In Search of Evolving Doctrine on a Changing Court: A Model for a Newer Equal Protection, 86 HARV. L. REV. 1, 8 (1972) (coining the "strict in theory, fatal in fact" line, though as to equal protection rather than free speech) (quotation marks omitted),

${ }^{69}$ Cf., e.g., State ex rel. Springer v. One 1940 Mercury 5-Passenger Coupe, 223 P.2d 121, 124 (Okla. 1950) (O’Neal, J., dissenting) (citing Justice Jackson's Brinegar dissent for the proposition that "Under some circumstances, depending somewhat on the gravity of the offense, it might be reasonable for an officer to stop any and all automobiles driving along a highway at a given point," and giving Justice Jackson's example of a child being kidnapped, but then applying the same logic to the search for a stolen car). 
to challenge the length of a prison term, the Court has generally deferred to legislative judgments of severity, largely because it has lacked a clear, defensible way to draw lines between offenses. In Ewing $v$. California, for instance, the Court upheld a 25-years-to-life sentence for a repeat offender who had been convicted of stealing merchandise worth $\$ 1,200$, and had a prior record that included a robbery, three burglaries, and various lesser offenses. In upholding the sentence, the Court did point to Ewing's criminal history, but it also stressed the need to defer to legislative judgments of gravity: Ewing's instant crime, the court said, "should not be taken lightly. . . . Theft of $\$ 1,200$ in property is a felony under federal law ... and in the vast majority of States. ..." And Ewing's sentence under the repeat offender statute "reflects a rational legislative judgment, entitled to deference, that offenders who have committed serious or violent felonies and who continue to commit felonies must be incapacitated."70

3. The text of the Excessive Fines Clause seems to require some judgment of severity, since often the excessiveness of a fine can only be determined relative to how severe the offense is. ${ }^{71}$ But even there, the Supreme Court's rule requires deference to the legislature. Fines are struck down only if they are "grossly disproportional,"72 and reviewing courts are to "grant substantial deference to the broad authority that legislatures necessarily possess in determining the types and limits of punishments for crimes.",73

The same can be expected in other situations. For instance, if courts conclude that the First Amendment requires them to distinguish speech based on the seriousness of the crime that the speech advocates or facilitates, they may feel similar pressure to "defer[]" to "rational legislative judgment" about the "gravity of the offense." Courts may be reluctant to distinguish, for instance, bans on publishing bomb-making information from bans on publishing drug-making information, ${ }^{74}$

${ }^{70} 123$ S. Ct. 1179, 1189-90 (2003). See also Barry L. Johnson, Purging the Cruel and Unusual, 2000 U. ILL. L. REV. 461, 504 (characterizing the Court's Cruel and Unusual Punishment Clause jurisprudence as resting partly on the fear that "strict proportionality review would promote inappropriate judicial activism in evaluating the seriousness of criminal offenses," because "proportionality determinations require inherently subjective comparisons of sentence severity with offense seriousness," comparisons that should instead "be left to legislatures, which are institutionally better positioned to determine the seriousness of a given offense").

${ }^{71}$ In some cases, such as in rem forfeiture cases, excessiveness might theoretically be determined without looking at the crime's severity, for instance using a per se rule that forfeiture of the instrumentality of a crime is per se not excessive. Compare United States v. Bajakajian, 524 U.S. 321, 344-47 (1998) (Kennedy, J., dissenting) (so arguing) with id. at 333-34 (rejecting this argument). But for a typical criminal fine, such an approach would be unavailable: The excessiveness judgment would have to consider the crime's severity.

${ }^{72} I d$. at 334.

${ }^{73}$ Id. (quoting Solem v. Helm, 463 U.S. 277, 290 (1983)).

${ }^{74}$ So far Congress has treated the two differently. Compare 18 U.S.C. $\S 842(\mathrm{p})$ (banning the distribution of certain kinds of speech that facilitate bomb-making) with S. 1428, 106th Cong., 1st Sess., sec. 9 (unsuccessfully proposing a similar ban as to speech related to drug-making). The 
given that many people find drug manufacturing to be as deadly as bomb manufacturing. ${ }^{75}$ And this may be true even if the judges might themselves view drug manufacturing as a less serious crime. ${ }^{76}$

Once courts have upheld bans on drug-makingand bomb -making information, they might be reluctant to take a different view as to newspaper articles that explain flaws in computer security systems and thus facilitate computer security violation, ${ }^{77}$ even though computer crime is just property crime rather than violent crime or drug crime. After all, computer crimes are often felonies (like the similar property crimes in Ewing or Sell, and can in the aggregate lead to very serious harm, such as the vast damage that computer viruses can cause. And once courts uphold bans on that information that facilitates computer crime, they may find it hard to distinguish, say, information that describes how people evade taxes, that tells people about copyrightinfringing sites, or that discusses holes in copy protection schemes ${ }^{78}$ - especially if Congress raises the penalties for such property crimes and the speech that facilitates them, thus announcing that it's taking the crimes especially seriously.

Such deference to legislatures seems particularly likely because many judges would find it both normatively and politically attractive. Deference avoids conflicts with legislators and citizens who firmly and plausibly argue that certain crimes are extremely serious, and who resent seeing those crimes treated as less constitutionally significant than other crimes. ${ }^{79}$ Deference shifts from the judges the burden of drawing and defending distinctions that don't rest on any crisp rules. Deference fits the notion that arbitrary line-drawing decisions, such as arbitrary gradations of crime, arbitrary threshold ages for driving or drinking, and so on are for the legislature rather than for judges. ${ }^{80}$

These are all good arguments for deference. The Court may have been correct in its cases dealing with the Cruel and Unusual Punishment Clause, the Excessive Fines

question is what might happen if Congress does ban the drug-making information.

${ }^{75}$ See Harmelin v. Michigan, 501 U.S. 957, 1002 (Kennedy, J., concurring in the judgment) (arguing that drug crimes are extremely serious); Eugene Volokh, Mechanisms of the Slippery Slope, 116 HARV. L. REV. 1026, 1056-71 (2003) (describing such "equality slippery slopes").

${ }^{76}$ See Yale Kamisar, "Comparative Reprehensibility" and the Fourth Amendment Exclusionary Rule, 86 Mich. L. REV. 1, 23-29 (1987) (asking, with regard to a serious crimes exception to the exclusionary rule, "Is a Short List of 'Serious Crimes' Likely To Stay Short?," and arguing that the answer is "no").

${ }^{77}$ See Volokh, Crime-Facilitating Speech, supra note 1, at pt. I (citing examples of such speech restrictions).

${ }^{78}$ See id. at pt. I (citing examples of such speech restrictions).

${ }^{79}$ See Volokh, Mechanisms of the Slippery Slope, supra note 75, at 1059-61.

${ }^{80}$ See Solem v. Helm, 463 U.S. 277, 308, 310 n.3 (1983) (Burger, C.J., dissenting); see also Luna, supra note 1, at 786-87 ("Even a sliding scale adopting limited categories of serious offenses will face tremendous pressure to expand upon those crimes exempted from the exclusionary rule. ... [T] he courts may be required to draw fine lines between different types of drugs as well as between kinds of drug offenses, reaching difficult conclusions of pharmacology and socio-economics and looking altogether legislative in operation.”). 
Clause, and the right to be free from involuntary antipsychotic medication, where it set a fairly low severity threshold for legislative action. But precisely because the arguments for deference are plausible, many judges who are asked to draw case-by case severity lines will over time come to draw the lines at a low level, treating most crimes as severe enough to justify the maximum latitude for the government.

\section{CONCLUSION}

As I said at the outset, this Essay can't generally answer the line-drawing questions with which it begins. But it has, I hope, offered some suggestions for how such answers can be provided. Let me recap them here.

1. It's probably wrong to say that courts should never draw constitutional lines distinguishing crimes based on their severity. True, it's hard to impose "rational limitations" that explain where an exception for especially severe or especially minor crimes will stop. True, there are problems with judges "distinguishing between the value of enforcing different criminal laws" and "making a value judgment that a legislature had declined to make." ${ }^{\prime 81}$ But there are problems with treating all crimes alike as well. I've pointed to many cases where courts have drawn severity lines. At least some of these lines, I think, must be drawn.

2. Moreover, there are several ways these severity lines may be drawn. The problems with any one line-drawing model (for instance, the case-by case approach discussed in Part V) should thus not by itself lead us to entirely renounce constitutional severity distinctions: One of the other approaches may well make more sense.

3. At the same time, the criticisms of constitutional line-drawing in this area do have considerable force. We may all agree that there is a difference between murder and littering, but it doesn't follow that courts can create administrable lines that distinguish the various cases between the two extremes. The sharpest lines are limited in number, so all the available ones may therefore fall in the wrong places; and many of the seemingly sharp lines are actually not as sharp as one might think.

As importantly, the less sharp lines may be unstable as well as vague. Over time, courts may become tempted to move the lines down, treating more and more crimes as severe. Yale Kamisar's question, "Is a Short List of 'Serious Crimes' Likely To Stay Short?," is worth keeping in mind. ${ }^{82}$

4. Judges and commentators who urge courts to draw constitutional severity distinctions should thus do more than just argue the value of distinguishing severe crimes from petty ones. They should also propose at least some specific potential distinctions, and explain why those distinctions are likely to work in practice. And this is especially so when the commentator is proposing not just one severity

\footnotetext{
${ }^{81}$ See Mincey v. Arizona and Branzburg v. Hayes, cited and discussed in Part II.

${ }^{82}$ See supra note 76.
} 
distinction, say between petty crimes and other crimes, but multiple gradations. ${ }^{83}$

The value of constitutional severity distinctions in the abstract should not be the issue. Here the devil is in the details. If courts can't make the severity distinctions work in practice, then the distinctions' merits in principle are of little consequence. And if courts can make them work in practice, then we might be able to live with their theoretical problems.

${ }^{83}$ See, e.g., Stuntz, O.J. Simpson, Bill Clinton, and the Transsubstantive Fourth Amendment, supra note 1. 